\title{
Paracoccidioides brasiliensis Isolated from Nine-Banded Armadillos (Dasypus novemcinctus) Reveal Population Structure and Admixture in the Amazon Basin
}

\author{
Eduardo Bagagli $^{1} \mathbb{D}$, Daniel Ricardo Matute ${ }^{2} \mathbb{D}$, Hans Garcia Garces $^{1} \mathbb{D}$, Bernardo Guerra Tenório ${ }^{3}$, \\ Adalberto Garcia Garces ${ }^{1}$, Lucas Gomes de Brito Alves ${ }^{3}$, Danielle Hamae Yamauchi ${ }^{1}{ }^{(D)}$, \\ Marluce Francisca Hrycyk ${ }^{4}$, Bridget Marie Barker ${ }^{5, *(\mathbb{D})}$ and Marcus de Melo Teixeira ${ }^{3,5, *(\mathbb{D})}$
}

1 Departamento de Microbiologia e Imunologia, Instituto de Biociências de Botucatu, Universidade Estadual Paulista/UNESP, Botucatu SP 18618-691, Brazil; eduardo.bagagli@unesp.br (E.B.);

atiestorage@gmail.com (H.G.G.); atiweb@gmail.com (A.G.G.); lucasgbalves@gmail.com (D.H.Y.)

2 Department of Biology, University of North Carolina, Chapel Hill, NC 27599, USA; dmatute@email.unc.edu

3 Faculdade de Medicina, Universidade de Brasília, Brasília DF 70910-900, Brazil;

danihyamauchi@gmail.com (B.G.T.); bernardoguerra320@gmail.com (L.G.d.B.A.)

4 Faculdade de Ciências Biológicas e Agrárias, Universidade do Estado de Mato Grosso, Campus de Alta Floresta, Alta Floresta MT 78580-000, Brazil; marluce@unemat.br

5 Pathogen and Microbiome Institute, Northern Arizona University, Flagstaff, AZ 86011, USA

* Correspondence: Bridget.Barker@nau.edu (B.M.B.); marcus.teixeira@gmail.com (M.d.M.T.)

Citation: Bagagli, E.; Matute, D.R.;

Garces, H.G.; Tenório, B.G.;

Garces, A.G.; Alves, L.G.d.B.;

Yamauchi, D.H.; Hrycyk, M.F.;

Barker, B.M.; Teixeira, M.d.M.

Paracoccidioides brasiliensis Isolated

from Nine-Banded Armadillos

(Dasypus novemcinctus) Reveal

Population Structure and Admixture in

the Amazon Basin. J. Fungi 2021, 7, 54

https://doi.org/10.3390/jof7010054

Received: 1 December 2020

Accepted: 23 December 2020

Published: 15 January 2021

Publisher's Note: MDPI stays neutral with regard to jurisdictional clai$\mathrm{ms}$ in published maps and institutional affiliations.

Copyright: (C) 2021 by the authors. Licensee MDPI, Basel, Switzerland. This article is an open access article distributed under the terms and conditions of the Creative Commons Attribution (CC BY) license (https:// creativecommons.org/licenses/by/ $4.0 /)$.

\begin{abstract}
Paracoccidioidomycosis is an endemic fungal disease to Latin America caused by at least five species-level genotypes of Paracoccidioides, named P. lutzii, P. brasiliensis (S1a and S1b populations), P. americana, P. restrepiensis, and P. venezuelensis. In this manuscript, we report on Paracoccidioides sp. sampling efforts in armadillos from two different areas in Brazil. We sequenced the genomes of seven Paracoccidioides isolates and used phylogenomics and populations genetics for genotyping. We found that P. brasiliensis and P. lutzii are both present in the Amazon region. Additionally, we identified two Paracoccidioides isolates that seem to be the result of admixture between divergent populations within P. brasiliensis sensu stricto. Both of these isolates were recovered from armadillos in a P. lutzii endemic area in Midwestern Brazil. Additionally, two isolates from human patients also show evidence of resulting from admixture. Our results suggest that the populations of $P$. brasiliensis sensu stricto exchange genes in nature. More generally, they suggest that population structure and admixture within species is an important source of variation for pathogenic fungi.
\end{abstract}

Keywords: Paracoccidioides; Amazon; armadillos; paracoccidioidomycosis; admixture

\section{Introduction}

Over 200 species of fungi have been reported to cause severe diseases in humans [1]. The Onygenalean fungi (Ascomycota, Eurotiomycetes) include a diverse array of endemic fungal pathogens that are tightly associated with many mammal species including humans. The fungi from these genera cause over 650,000 infections a year [2]. The infections caused by these fungi are most often triggered by the inhalation of infectious conidia or spores that undergo a dimorphic switch inside the lungs to yeast-like cells, provoking life-threatening diseases [3]. This morphological transformation is regulated by temperature, which has led to the hypothesis that the pathogens exists as mycelia in soil and as a yeast in animal reservoirs [4].

Among these fungi, the genus Paracoccidioides is of particular importance because it is almost exclusively diagnosed in Latin America and causes the most prevalent systemic mycosis in South America, paracoccidioidomycosis (PCM) [5]. The genus harbors five species, all of which are human pathogens [6-11]. Three of these species, P. brasiliensis, P. americana, and P. lutzii, are all widely distributed across the South American continent. 
The other two species, P. restrepiensis and P. venezuelensis, are restricted to Colombia and Venezuela, respectively $[8,10,12,13]$. The only species with extensive geographic sampling, P. brasiliensis, shows a strong population structure and harbors two distinct populations, named S1b and S1a, which have overlapping geographical occurrences in Southern Brazil, Argentina, and Paraguay [12]. Paracoccidioides lutzii is predominantly found in Amazon and Midwestern Brazil, and P. americana is found primarily in Southeastern Brazil, with a single report in Venezuela [8].

Dimorphic fungi have been isolated from soil and from mammal reservoirs. Armadillos, for example, are commonly animal reservoirs of Paracoccidioides. Paracoccidioides brasiliensis and P. americana have been isolated from Dasypus novemcinctus in Brazil [14-17], whereas $P$. restrepiensis was retrieved from Cabassous centralis specimens in Colombia [18]. DNA-based tests suggest the occurrence of these fungi in aerosols and soil samples obtained in the burrows of those mammals $[14,19]$. This association is not exclusive for Paracoccidioides; Coccidioides [20] and Histoplasma [21] have been isolated from armadillo tissues and their burrows. Collectively, these findings suggest that armadillos are a common reservoir for these pathogens [15].

In spite of the clear association between armadillos and Paracoccidioides, just a handful of isolates of this fungus obtained from armadillos have ever been sequenced. Three P. brasiliensis, one P. americana (São Paulo, Brazil), and one P. restrepiensis (Caldas, Colombia) isolates derived from armadillos had their genomes fully sequenced [13]. This paucity of genetic data from isolates from mammal reservoirs is particularly critical for the Amazon basin, one of the regions with the highest prevalence for PCM $[5,22]$. Here we aimed to bridge this gap by collecting Paracoccidioides isolates from armadillos from the Amazon and Southern Brazil and comparing their genotypes to previously sequenced genomes.

The genomes of the seven Paracoccidioides strains were sequenced, and we compared their genotypes to other animal and human-derived strains. Phylogenetic and population genetic analyses reveal that all the seven isolates belong to Paracoccidioides brasiliensis sensu stricto. We also found that two of these isolates are admixed and novel genotypes from $\mathrm{S} 1 \mathrm{a}$ and $\mathrm{S} 1 \mathrm{~b}$ populations of $P$. brasiliensis. Our results suggest that intraspecific structure and admixture can be an important sources of variation in P. brasiliensis sensu stricto, and propose new mechanisms regarding the drivers of intraspecific variation in each of the species of Paracoccidioides.

\section{Materials and Methods}

\subsection{Armadillos Capture, Euthanasia, and Fungal Isolation}

We captured six armadillos (Dasypus novemcinctus), four in São Paulo (Southeastern Brazil), and two in Mato Grosso (Midwestern, Brazil), using cage traps placed on the animal track or at the entrance of the armadillo's burrow (Table 1). The permission for capturing and euthanizing the armadillos was obtained at the Instituto Brasileiro do Meio Ambiente e dos Recursos Naturais Renováveis, Instituto Chico Mendes (IBAMA/ICMBio-License number 30585-1) and at the Ethics Committee on the Use of Animals approved by the Biosciences Institute/UNESP (CEUA, protocol number 737, May 21th, 2015) in agreement with the National Council for the Control of Animal Experimentation, Brazilian Society of Science in Laboratory Animals (CONCEA) regulations. Hrycyk et al. describe the procedure in detail [19]. Briefly, the armadillos were submitted to euthanasia by injecting a combination of ZoletylR 50-Virbac, $0.2 \mathrm{~mL} / \mathrm{kg}$ intramuscularly, as well as by cardiac puncture. Aseptically collected livers, spleens, and mesenteric lymph nodes were cleaned in $70 \%(v / v)$ alcohol, to remove unwanted contaminants and washed again in a sterile saline solution $(0.9 \% w / v)$. Fragments ranging from 2 to $3 \mathrm{~mm}$ of the collected organs were cultivated in Mycosel Agar plates supplemented with gentamicin $(50 \mu \mathrm{g} / \mathrm{mL})$. The plates were incubated at $35{ }^{\circ} \mathrm{C}$, for up to 45 days, and colonies with suspected morphology compatible with Paracoccidioides spp. were subcultured in Glucose Peptone Yeast Extract Agar (GPY). Seven armadillo-derived strains, five from Southeastern Brazil and two from Midwestern Brazil, were selected for whole genome sequencing, and the host characteristics, such as 
species, sex, weight, organ of isolation, and precise location, were collected (Figure 1A and Table 1).

\subsection{DNA Extraction, Library Preparation and Genome Sequencing}

We used standard protocols for the extraction of DNA from fungal cells. Briefly, yeast cells of Paracoccidioides were disrupted using $0.5 \mathrm{~mm}$ beads and lysis buffer at the Precellys tissue homogenizer (Bertin Technologies, Rockville, MD, USA). Next, the DNA was extracted according to [19] and was quantified by using a Nanodrop 3300 fluorimeter stained with the PicoGreen dsDNA quantitation reagent (ThermoFisher, Waltham, MA, USA). About $1 \mu \mathrm{g}$ of DNA was fragmented and used as input to prepare DNA pairedend libraries, using the KAPA HTP Library Preparation Kit. We used the KAPA Library Quantification Kit Illumina ${ }^{\circledR}$ Platforms (Roche Sequencing Solutions, Pleasanton, CA, USA) to quantify the libraries via GPCR and then pooled them in a single Illumina flow cell. Sequencing was performed in an Illumina NextSeq 550 system (Illumina, San Diego, CA, USA), using a High Output Kit v2 (300 cycles), $2 \times 150$ bp. We used paired barcodes to de-multiplex reads, and individual read quality control was performed by using inhouse methods.

\subsection{Read Mapping and Single Nucleotide Polymorphism (SNP) Calling}

We mapped the newly generated reads and reads from 63 previously sequenced Paracoccidioides isolates ([12], Supplementary Materials Table S1), to the P. brasiliensis Pb18 v2 assembly (ABKI00000000.2), using bwa v0.7.7 [23]. To identify Single Nucleotide Polymorphisms (SNPs), we used the NASP pipeline [24] after doing the following: (i) aligning trimmed and quality-filtered reads into the reference; (ii) re-aligning mapped reads to their corresponding reference genome via RealignerTargetCreator and IndelRealigner toolkits of GATK v3.3-0 to purge suspicious intervals; (iii) calling SNPs, using UnifiedGenotyper tool of GATK v3.3-0 - the parameter "het" was set to 0.01 ; (iv) filtering resulting.vcf files, using the parameters QD $=2.0||$ FS_filter $=60.0||$ MQ_filter $=30.0$ | | MQ_Rank_Sum_filter $=-12.5$ | | Read_Pos_Rank_Sum_filter $=-8[25,26]$; and finally (v) removing SNPs with a coverage lower than 10X coverage across all samples or that were identified as being within duplicated regions in the reference by NUCmer [27].

Table 1. Strain, host, sex, host weight, location, geographical coordinates, organ, and genotypes for each of the strains analyzed by whole genome sequencing.

\begin{tabular}{|c|c|c|c|c|c|c|c|}
\hline Strain & Host & Sex & $\begin{array}{c}\text { Host Weight } \\
\text { (kg) }\end{array}$ & Geographic Area & Coordinates * & Organ & Genotype \\
\hline T17LM2 & D. novemcinctus & male & 4.7 & $\begin{array}{c}\text { Southeast, SP } \\
\text { (Botucatu) }\end{array}$ & $\begin{array}{l}22^{\circ} 48^{\prime} 02^{\prime \prime} \mathrm{S} / \\
48^{\circ} 23^{\prime} 24^{\prime \prime} \mathrm{W}\end{array}$ & $\begin{array}{c}\text { Mesenteric } \\
\text { Lymph node }\end{array}$ & S1a \\
\hline T17LM3 & D. novemcinctus & male & 4.7 & $\begin{array}{c}\text { Southeast, SP } \\
\text { (Botucatu) }\end{array}$ & $\begin{array}{l}22^{\circ} 48^{\prime} 02^{\prime \prime} \mathrm{S} / \\
48^{\circ} 23^{\prime} 24^{\prime \prime} \mathrm{W}\end{array}$ & $\begin{array}{c}\text { Mesenteric } \\
\text { Lymph node }\end{array}$ & S1a \\
\hline T18LM1 & D. novemcinctus & male & 3.9 & $\begin{array}{c}\text { Southeast, SP } \\
\text { (Botucatu) }\end{array}$ & $\begin{array}{l}22^{\circ} 48^{\prime} 02^{\prime \prime} \mathrm{S} / \\
48^{\circ} 23^{\prime} 24^{\prime \prime} \mathrm{W}\end{array}$ & $\begin{array}{l}\text { Mesenteric } \\
\text { Lymph node }\end{array}$ & S1a \\
\hline T22LM1 & D. novemcinctus & female & 3.9 & $\begin{array}{l}\text { Southeast, SP } \\
\text { (São Manoel) }\end{array}$ & $\begin{array}{l}22^{\circ} 34^{\prime} 16^{\prime \prime} \mathrm{S} / \\
48^{\circ} 25^{\prime} 18^{\prime \prime} \mathrm{W}\end{array}$ & $\begin{array}{c}\text { Mesenteric } \\
\text { Lymph node }\end{array}$ & S1a \\
\hline T23LM1 & D. novemcinctus & male & 4.3 & $\begin{array}{l}\text { Southeast, SP } \\
\text { (São Manoel) }\end{array}$ & $\begin{array}{l}22^{\circ} 34^{\prime} 16^{\prime \prime} \mathrm{S} / \\
48^{\circ} 25^{\prime} 18^{\prime \prime} \mathrm{W}\end{array}$ & $\begin{array}{c}\text { Mesenteric } \\
\text { Lymph node }\end{array}$ & S1a \\
\hline T19F33 & D. novemcinctus & male & 6.0 & $\begin{array}{l}\text { Midwest, MT } \\
\text { (Alta Floresta) }\end{array}$ & $\begin{array}{l}10^{\circ} 04^{\prime} 23^{\prime \prime} \mathrm{S} / \\
56^{\circ} 09^{\prime} 34^{\prime \prime} \mathrm{W}\end{array}$ & Liver & $\mathrm{S} 1 \mathrm{a} / \mathrm{S} 1 \mathrm{~b}$ \\
\hline T20B15 & D. novemcinctus & male & 6.0 & $\begin{array}{l}\text { Midwest, MT } \\
\text { (Alta Floresta) }\end{array}$ & $\begin{array}{l}10^{\circ} 04^{\prime} 23^{\prime \prime} \mathrm{S} / \\
56^{\circ} 09^{\prime} 34^{\prime \prime} \mathrm{W}\end{array}$ & Spleen & $\mathrm{S} 1 \mathrm{a} / \mathrm{S} 1 \mathrm{~b}$ \\
\hline
\end{tabular}




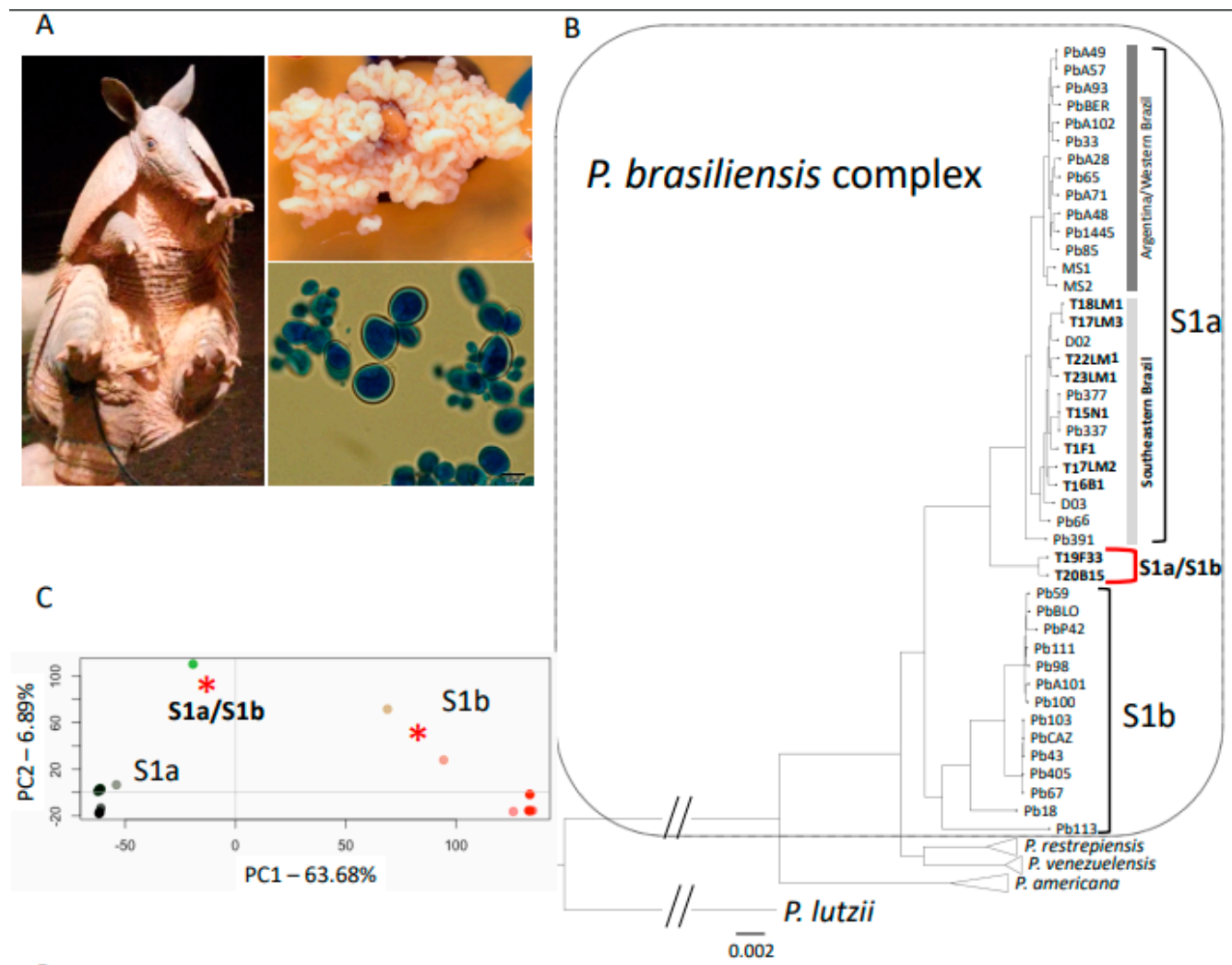

D
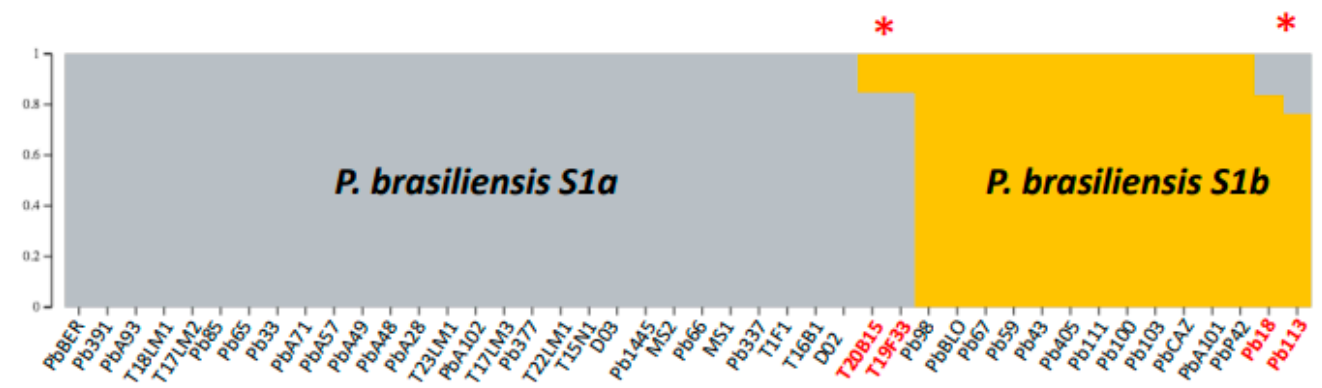

Figure 1. Genetic background of Paracoccidioides brasiliensis isolated from nine-banded armadillos in the Amazon basin. (A) Specimen collected, macroscopic characteristics of the fungal growth on tissue, and microscopic characteristics of yeast cells isolated from the tissue. (B) Genome-level maximum likelihood tree of 70 Paracoccidioides spp. genomes, indicating the placement of the Amazonian isolates T19F33 and T20B15 as a monophyletic group sister to P. brasiliensis S1a cluster. (C) Principal Component Analysis (PCA) reveals that P. brasiliensis S1a and S1b are populations separated along the PC1 axis corresponding to $63.68 \%$ of the total variation. (D) ADMIXTURE analysis of $P$. brasiliensis revealed admixed ${ }^{*}$ ) S1a genotypes (T19F33 and T20B15) and S1b genotypes (Pb113 and Pb18). The proportion of admixture of each isolate is represented by height and colors of each of the two populations.

\subsection{Phylogenetic Analysis}

We used the SNP matrix to determine the phylogenetic placement of the Paracoccidioides spp. isolates obtained from armadillos. We did a Maximum Likelihood phylogenetic analysis with a total of 70 strains (63 previously sequenced and seven from this report). To generate the maximum likelihood tree, we loaded the SNP matrix into IQTREE v1.6.12 [28]. The best substitution SNP model was calculated by using the -m MFP function (ModelFinder) [29]. Since all the seven newly sequenced isolates we report here belong to P. brasiliensis sensu stricto (see Section 3), we rooted the tree with P. lutzii. To determine the support for the topology, we calculated support for each branch, using 1000 ultrafast bootstrap replicates coupled with a Shimodaira-Hasegawa-like approximate likelihood ratio test (SH-aLRT) $[30,31]$. 


\subsection{Admixture Analyses}

We studied whether any of the newly sequenced isolates showed evidence of being admixed. We used two complementary approaches. First, we visualized the arrangement of genetic variation within P. brasiliensis by using Principal Component Analysis (PCA). Similar analyses for the full Paracoccidioides genus can be found elsewhere [7,12]. We used the $\mathrm{R}$ package adegenet [32]. We only used biallelic sites extracted with the function fasta2genlight. To calculate the PCs, we used the function $g l P c a$. We restricted our analyses to the first two principal components (PCs), as they encompass most of the genetic variability (see Results). Second, we estimated the proportions of admixture in potentially admixed individuals, as revealed by the PCA. The phylogenetic tree revealed the existence of two populations (S1a and S1b; see Results and References [12,13]). We used ADMIXTURE [33] and conditioned the number of populations to be two $(K=2)$. This prior was based on the existence of the S1a and S1b populations. This analysis reveals the contribution of each of these two populations to the ancestry of each isolate within P. brasiliensis sensu stricto [34]. Please note that other ADMIXTURE scenarios might be more likely, but they do not serve to resolve the contributions of S1a and S1b to individual isolates. The proportion of admixture for each individual was plotted by using Structure Plot v2.0-http:/ / omicsspeaks.com/ strplot2/ [35].

\section{Results}

\subsection{Genomic Data}

We obtained genomic data for seven P. brasiliensis isolates recovered from armadillos in two different endemic areas of PCM. The sequencing coverage ranged between $43.29 \times$ and $63.75 \times$ per site. Raw Illumina paired-end reads were deposited at the Sequence Read Archive (SRA), under the following deposit number SRR13267631- SRR13267637. After aligning the Illumina reads to the reference sequence and calling SNPs by using the GATK filters described in Reference [12], we generated a nucleotide matrix containing 831,476 polymorphic sites across all Paracoccidioides species. The matrix that included only strains from the P. brasiliensis species complex had 270,464 SNPs, which is consistent with the divergence between P. lutzii and the species from the brasiliensis complex.

\subsection{Phylogenetic Tree}

Using the SNP matrix, we generated a maximum likelihood phylogenetic tree. As expected, a rooted phylogenetic tree with $P$. lutzii recovered all the four species within the $P$. brasiliensis species complex. Consistent with previous reports [12], we found that P. brasiliensis is formed by two structured populations previously deemed S1a and S1b. S1a is, in turn, composed of two subpopulations which follow a geographical pattern: One of the subpopulations is mostly found in Argentina and Eastern Brazil, while the other one is found in Southeastern Brazil. Our focus was to understand the genealogical relationships of the isolates collected from armadillos. The five isolates we recently collected from armadillos in Southwest Brazil and three previously collected isolates (T1F1, T15N1, and T16B1 [12,13]) appear within S1a and consistent with their geographical origin and are associated with the southeast subpopulation of $P$. brasiliensis sensu stricto. The isolates T22LM1, T23LM1, and T17LM2 were previously classified as S1b strains, using the gp43 gene as a genetic marker [19], which highlights the potential for incorrect phylogenetic assignment when using a single locus as a proxy of ancestry. We obtained two distinct samples from a single armadillo (T17). While they are both assigned to the S1a population, they are not identical isolates. First, their position in the tree shows they are not each other's closest relatives. For each of these two isolates, the closest identified relatives are other armadillo and clinical isolates. Second, a genome comparison shows alleles that are distinct, thus confirming they are not identical (Dxy $=7.38 \times 10^{-4}$, Figure 2). The two of the armadillo isolates from the Amazon, T19F33 and T20B15, appear as a monophyletic group that is a sister clade to S1a, which might indicate the existence of an Amazon population 
within P. brasiliensis (Figure 1), a hypothesis we explore more deeply in the following section (see Section 3.3).

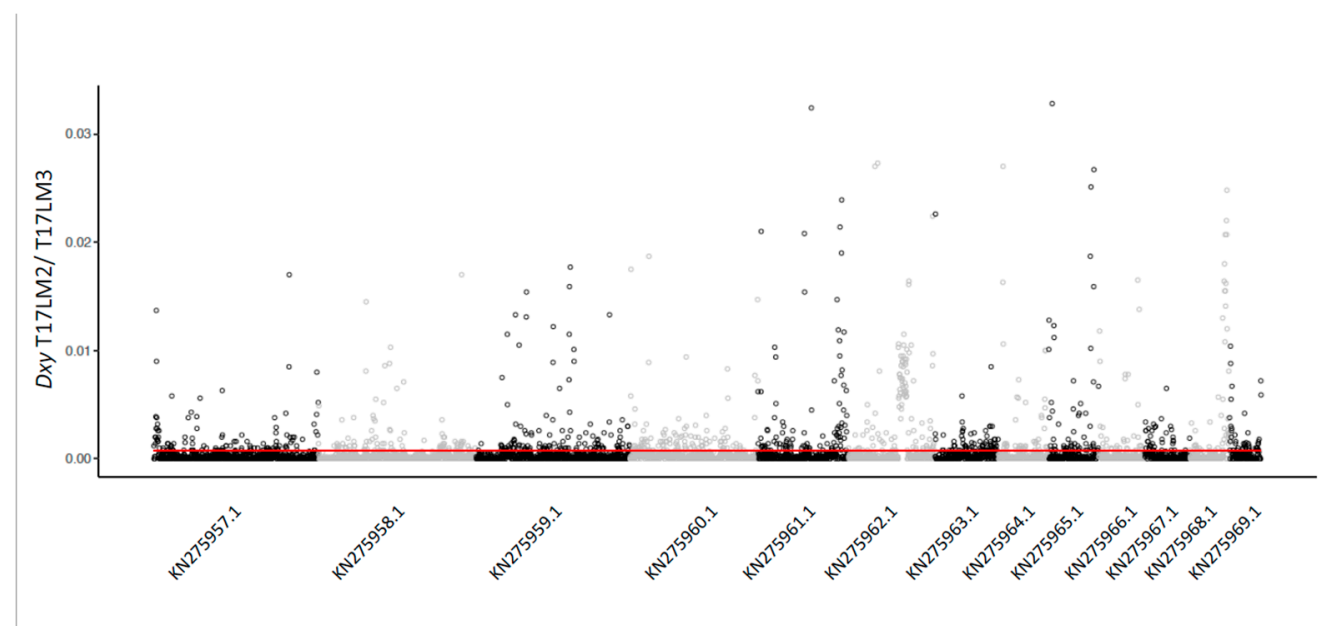

Figure 2. Whole-genome genetic distances between the isolates T17LM2 and T17LM3. Absolute genetic distance (dXY) between the isolates T17LM2 and T17LM3 were calculated by using $5 \mathrm{~kb}$ sliding window blocks and plotted across 13 largest scaffolds of the P. brasiliensis $\mathrm{Pb} 18$ reference genome.

Most S1b isolates appear as part of two monophyletic groups. These two subpopulations broadly, but not perfectly, correspond to Argentina and Paraguay. Two isolates within S1b appear as deep branches with S1b and are not included in either of these two populations. $\mathrm{Pb} 113$ and, to a lesser extent, $\mathrm{Pb} 18$ (Figure 1B) appear to be lone branches within S1b. The phylogenetic signal from the T19F33/T20B15 dyad (classified in the tree as S1a) could be a true monophyletic clade, or it could be the result of conflicting phylogenetic signal in the genome. A similar occurrence could explain the phylogenetic position of $\mathrm{Pb} 113$ and $\mathrm{Pb} 18$ (classified in the tree as $\mathrm{S1b}$ ). As a result of this observation, we explored the possibility of gene flow and patterns of admixture within P. brasiliensis sensu stricto.

\subsection{Admixture}

We investigated the partitioning of genetic variation within P. brasiliensis sensu stricto using genome-wide polymorphisms. Principal Component Analysis (PCA) biplots show that $P$. brasiliensis $\mathrm{S} 1 \mathrm{a}$ and $\mathrm{S} 1 \mathrm{~b}$ are separated along the $\mathrm{PC} 1$ axis, which corresponds to $63.68 \%$ of the variance within the P. brasiliensis species (Figure 1C). Notably, the two S1a armadillo strains from the Amazon (T19F33 and T20B15) and Pb113 and Pb18 appear as intermediates between the two $P$. brasiliensis populations. Indeed, the distant phylogenetic position of these four isolates may be due to admixed ancestry of S1a and S1b. PC2 explains only $\sim 5 \%$ of the total variance and seems to correspond to variants present in the Amazon armadillo strains. Next, we quantified the admixture proportions of these genetically intermediate isolates. As expected, when we forced ADMIXTURE to detect two groups within P. brasiliensis sensu stricto, we found that the two clusters correspond to S1a and S1b (Figure 1D). As suggested by the PCA, both Amazonian armadillo strains, T19F33 and T20B15, had evidence of admixed genotypes between the P. brasiliensis S1a and S1b. The proportion of admixture in both isolates was similar: S1a, 85\%; S1b,15\% (Figure 1D). Pb18 and $\mathrm{Pb} 113$ also show admixed genotypes (16 and 23\% from S1a, respectively, and the rest from S1b).

\section{Discussion}

Here we report our analysis of the genomes of seven isolates of Paracoccidioides isolated from six armadillos in the Amazon basin and Southern Brazil. Our results are relevant to three general aspects of the biology of Paracoccidioides: (i) the reinforcement of the close association of Paracoccidioides with armadillos and the potential role these animals play 
as an important reservoir for the fungus, (ii) the co-infection of a single armadillo with multiple isolates, and (iii) the extent of population structure and admixture within species of Paracoccidioides. We discuss each of these aspects as follows.

\subsection{Paracoccidioides and Armadillos}

The association between armadillos and Paracoccidioides has been hypothesized since the 1960s [36] and confirmed in the 1980s [17]. So far, 140 armadillos (including six from the current work) have been euthanized by different research groups in six different states/endemic zones of the Paracoccidioides; 53 animals were positive and 87 were negative for fungal growth (Table S1). However, the association between armadillos and Paracoccidioides remains largely understudied. Three different species of Paracoccidioides have been isolated from two species of armadillos: Dasypus novemcinctus and Cabassous centralis. A single report detected DNA of Paracoccidioides sp. in tissue samples of a Dasypus septemcinctus road-killed specimen [37]. The most commonly isolated species from $D$. novemcinctus has been $P$. brasiliensis sensu stricto. Out of the 39 isolates that have been obtained and genotyped from $D$. novemcinctus, 37 belong to $P$. brasiliensis sensu stricto, and most of the strains genotyped by whole genome analysis fit into the population S1a (Supplementary Materials Table S2, $[9,12,13,19])$. Whether this pattern is the result of limited sampling effort and sample size, focused in localities where S1a is endemic, or whether S1a is more likely to infect armadillos, will remain unknown until a comprehensive sampling of these mammals is completed across the endemic regions. Paracoccidioides americana has been isolated from Dasypus novemcinctus on two occasions (T10 and T18; Table 1, [9,19]). Paracoccidioides restrepiensis has been isolated from two different species: D. novemcinctus [38] and C. centralis [18]. This latter species of armadillo is restricted to the northern part of South America and Central America, and the only species of Paracoccidioides that overlaps with C. centralis' range is $P$. restrepiensis. The two other species of Paracoccidioides that have not been isolated from armadillos are P. lutzii and P. venezuelensis. Both species remain sparsely sampled and it is premature to conclude whether or not they infect armadillos.

An unknown aspect of the relationship between armadillos and fungal pathogens, and in particular of Paracoccidioides, is whether additional species of armadillos, besides D. novemcinctus and C. centralis, are susceptible to fungal infections. The genera Dasypus and Cabassous, the two known armadillo reservoirs of Paracoccidioides, diverged approximately 45 million years ago. Dasypus, the only genus within the family Dasypodidae, contains seven extant species; Cabassous belongs to the family Chlamyphoridae, which harbors 14 extant species. Whether or not the other 21 armadillo species are infected with Paracoccidioides, or with other fungi, remains an open question. PCR surveys in autopsied tissues suggest the presence of Paracoccidioides in other armadillo species, but, to date, no isolate has been obtained (Supplementary Materials Table S1, [37]). There is some evidence that armadillos are not the only animal reservoir of Paracoccidioides. For example, Paracoccidioides infections are not rare in dogs [39,40]. Roadkill samples of Didelphis albiventris, Gallictis vittata, Procyon cancrivorus, and Sphiggurus spinosus tested positive for Paracoccidioides DNA [37]. A southern two-toed sloth captured in French Guiana showed signs consistent with a PCM infection [41]. Anti-P. lutzii and anti-P. brasiliensis antibodies have been reported in wild and domestic animals in Southern Brazil, suggesting that natural infections of both species might occur [42]. The co-evolutionary association of these organisms remains an underdeveloped area of medical mycology and other infectious diseases. In general, the ecology and life history of Paracoccidioides remain largely unknown, and a concerted community effort will be required to identify ecological features important for the distribution of each of the species in the genus.

\subsection{Coinfection by Multiple Isolates}

One of the armadillos (T17) showed coinfection by two different isolates of P. brasiliensis (Figure 1B). Coinfections suggest the potential of close contact within animal reservoirs 
and have two major implications. First, they suggest the possibility of recombination within animal reservoirs, a phenomenon observed in Candida albicans [43]. Alternatively, different isolates could exclude each other and be partitioned in different tissues or niches. Interestingly, at least one armadillo was confirmed to be co-infected with P. americana and P. brasiliensis simultaneously (sample T18, [19]). This co-infection is prima facie evidence that $P$. brasiliensis sensu stricto and P. americana share an ecological niche, have the opportunity to interbreed, and yet they show no evidence of gene exchange. Because little is known about gene exchange and frequency of sexual recombination in these organisms, the identification of barriers to gene flow are not currently known.

\subsection{Population Structure and Admixture}

The advent of genomics has revealed that species and populations hybridize and exchange genes much more than previously thought. In the case of Paracoccidioides, there has been an emphasis to determine whether different species in the genus hybridize and exchange genes $[7,44]$. While recently diverged species (e.g., P. restrepiensis vs. P. venezuelensis) show some minimal evidence for interspecific admixture, the most divergent species (e.g., P. americana and any other species) show no evidence of interspecific gene flow [44]. Other fungal pathogens from the same family also show some evidence of gene exchange between species $[45,46]$. In this report, we identified four isolates with evidence of admixed ancestry from structured populations within P. brasiliensis sensu stricto. Admixtures are now known to be much more common than previously thought [12]. The possibility of hybridization and admixture generating allelic combinations that can be selected upon will depend on the density of alleles that increased fitness in the recipient population, the density of hybrid incompatibilities, and the recombination rates between positively and negatively selected alleles [47-49]. In this report, we focused on the magnitude of gene exchange between populations of the most-extensively sampled species of Paracoccidioides and P. brasiliensis sensu stricto. Interspecific hybrids can serve as a bridge for gene exchange, but their fitness is often reduced because of hybrid incompatibilities. Admixed individuals from different populations, but from the same species, are less likely to show fitness defects (because there is lower chances of hybrid incompatibility [50-52]) and admixture is more likely to generate allelic combinations that can be favored by selection [53]. The genomes of isolates from Amazonian armadillos revealed that populations within P. brasiliensis interbreed and exchange genes. Moreover, clinical isolates from Southern Brazil also have admixed origin between the same populations, suggesting that the admixture between these two populations might occur over a large geographical scale. Alternatively, it might be that admixture only occurs in a single location, but there has been migration of admixed genotypes. Since patients are more likely than armadillos to move thousands of miles, if there has been movement, it is more likely that the admixture occurred in the Amazon.

\section{Conclusions}

Studies on Paracoccidioides have focused on the partition of genetic diversity among cryptic species. The last fifteen years have seen the identification of five previously undescribed species within the genus $[7,11]$. This robust taxonomic classification, which includes morphological traits and molecular markers to identify Paracoccidioides species, should be the launching point in defining processes that drive the evolution of Paracoccidioides species and populations. In this report, we showed that population structure and intraspecific admixture might be important contributors to genetic diversity within fungal species. Our results, and others previously published $[14,15,19]$, have revealed that armadillos are commonly infected by P. brasiliensis, P. americana, and P. restrepiensis, but not by P. lutzii. As of now, the only reliable isolate retrieval mechanism is to sacrifice the animal or to collect them postmortem (e.g., roadkill, [37]). The development of non-lethal sampling would increase the possibility of recovering isolates at much higher rates, and thus improve our understanding of the basic biology, genetics, and ecology of the fungus. Only denser sampling of isolates and a precise quantification of their levels of admixture will reveal 
the true biogeographic structure of intraspecific allele exchange within P. brasiliensis sensu stricto.

Supplementary Materials: The following are available online at https:/ / www.mdpi.com/2309-6 08X/7/1/54/s1. Table S1: Species of armadillo, number of individuals sampled, and positive and negative animals tested so far for the isolations of Paracoccidioides spp. Table S2: Paracoccidioides sp. armadillos isolate name and species diagnosed. References [54-56] were cited in the Supplementary Materials.

Author Contributions: Conceptualization, E.B., D.R.M., and M.d.M.T.; methodology, H.G.G., B.G.T., L.G.d.B.A., D.H.Y., and M.F.H.; software, A.G.G. and B.M.B.; formal analysis, E.B., H.G.G., A.G.G., D.H.Y., M.F.H., and M.d.M.T.; investigation, E.B. and B.M.B.; resources, E.B., B.M.B., and M.d.M.T.; data curation, M.d.M.T. and D.R.M.; writing—original draft preparation, M.d.M.T. and E.B.; writingreview and editing, D.R.M., B.M.B., and M.d.M.T. All authors have read and agreed to the published version of the manuscript.

Funding: This project was funded by the Conselho Nacional de Ciência e Tecnologia (CNPq), under contract no. 460999/2014-1 and by the Fundação de Amparo a Pesquisa do Estado de São Paulo (FAPESP), grant no. 2018/06390-9. D.R.M. is supported by NIH/NIGMS R01GM121750. B.M.B was supported by NIH/NIAID award R21AI28536, ADHS17-0007403, and ADHS16-162415. The content is solely the responsibility of the authors and does not necessarily represent the official views of the NIH.

Institutional Review Board Statement: The study was conducted according to the guidelines of the Declaration of Helsinki, and approved by the Ethics Committee of Biosciences Institute/Universidade Estadual de São Paulo (UNESP / Botucatu), protocol number 737, 21 May 2015, in agreement with the National Council for the Control of Animal Experimentation, Brazilian Society of Science in Laboratory Animals (CONCEA) regulations.

Informed Consent Statement: Not applicable.

Data Availability Statement: Genomic data supporting the herein reported results can be found at BioProject PRJNA685988.

Acknowledgments: We are tankful to Bodo Wanke for his discussions, enthusiasm, and knowledge about the ecology and evolution of Paracoccidioides and other dimorphic fungal pathogens.

Conflicts of Interest: The authors declare no conflict of interest.

\section{References}

1. Fisher, M.C.; Gurr, S.J.; Cuomo, C.A.; Blehert, D.S.; Jin, H.; Stukenbrock, E.H.; Stajich, J.E.; Kahmann, R.; Boone, C.; Denning, D.W.; et al. Threats Posed by the Fungal Kingdom to Humans, Wildlife, and Agriculture. mBio 2020, 11. [CrossRef] [PubMed]

2. Van Dyke, M.C.C.; Teixeira, M.M.; Barker, B.M. Fantastic yeasts and where to find them: The hidden diversity of dimorphic fungal pathogens. Curr. Opin. Microbiol. 2019, 52, 55-63. [CrossRef] [PubMed]

3. Sil, A.; Andrianopoulos, A. Thermally Dimorphic Human Fungal Pathogens-Polyphyletic Pathogens with a Convergent Pathogenicity Trait. Cold Spring Harb. Perspect. Med. 2014, 5, a019794. [CrossRef] [PubMed]

4. Gauthier, G.M. Dimorphism in fungal pathogens of mammals, plants, and insects. PLoS Pathog. 2015, 11, e1004608. [CrossRef] [PubMed]

5. Martinez, R. New Trends in Paracoccidioidomycosis Epidemiology. J. Fungi 2017, 3, 1. [CrossRef]

6. Matute, D.R.; McEwen, J.G.; Puccia, R.; Montes, B.A.; San-Blas, G.; Bagagli, E.; Rauscher, J.T.; Restrepo, A.; Morais, F.; Nino-Vega, G.; et al. Cryptic speciation and recombination in the fungus Paracoccidioides brasiliensis as revealed by gene genealogies. Mol. Biol. Evol. 2006, 23, 65-73. [CrossRef]

7. Turissini, D.A.; Gomez, O.M.; Teixeira, M.M.; McEwen, J.G.; Matute, D.R. Species boundaries in the human pathogen Paracoccidioides. Fungal Genet. Biol. 2017, 106, 9-25. [CrossRef]

8. Teixeira, M.M.; Theodoro, R.C.; Nino-Vega, G.; Bagagli, E.; Felipe, M.S. Paracoccidioides species complex: Ecology, phylogeny, sexual reproduction, and virulence. PLoS Pathog. 2014, 10, e1004397. [CrossRef]

9. Theodoro, R.C.; Teixeira Mde, M.; Felipe, M.S.; Paduan Kdos, S.; Ribolla, P.M.; San-Blas, G.; Bagagli, E. Genus paracoccidioides: Species recognition and biogeographic aspects. PLoS ONE 2012, 7, e37694. [CrossRef]

10. Teixeira, M.M.; Theodoro, R.C.; de Carvalho, M.J.; Fernandes, L.; Paes, H.C.; Hahn, R.C.; Mendoza, L.; Bagagli, E.; San-Blas, G.; Felipe, M.S. Phylogenetic analysis reveals a high level of speciation in the Paracoccidioides genus. Mol. Phylogenet. Evol. 2009, 52, 273-283. [CrossRef] 
11. Teixeira Mde, M.; Theodoro, R.C.; Oliveira, F.F.; Machado, G.C.; Hahn, R.C.; Bagagli, E.; San-Blas, G.; Soares Felipe, M.S. Paracoccidioides lutzii sp. nov.: Biological and clinical implications. Med. Mycol. 2014, 52, 19-28. [CrossRef] [PubMed]

12. de Melo Teixeira, M.; Emilia Cattana, M.; Matute, D.R.; Fernando Munoz, J.; Arechavala, A.; Isbell, K.; Schipper, R.; Santiso, G.; Tracogna, F.; de Los Angeles Sosa, M.; et al. Genomic diversity of the human pathogen Paracoccidioides across the South American continent. Fungal Genet. Biol. 2020. [CrossRef]

13. Munoz, J.F.; Farrer, R.A.; Desjardins, C.A.; Gallo, J.E.; Sykes, S.; Sakthikumar, S.; Misas, E.; Whiston, E.A.; Bagagli, E.; Soares, C.M.; et al. Genome Diversity, Recombination, and Virulence across the Major Lineages of Paracoccidioides. $m S p h e r e$ 2016, 1. [CrossRef] [PubMed]

14. Arantes, T.D.; Theodoro, R.C.; Teixeira Mde, M.; Bosco Sde, M.; Bagagli, E. Environmental Mapping of Paracoccidioides spp. in Brazil Reveals New Clues into Genetic Diversity, Biogeography and Wild Host Association. PLoS Negl. Trop. Dis. 2016, 10, e0004606. [CrossRef]

15. Bagagli, E.; Bosco, S.M.; Theodoro, R.C.; Franco, M. Phylogenetic and evolutionary aspects of Paracoccidioides brasiliensis reveal a long coexistence with animal hosts that explain several biological features of the pathogen. Infect. Genet. Evol. 2006, 6, 344-351. [CrossRef]

16. Bagagli, E.; Sano, A.; Coelho, K.I.; Alquati, S.; Miyaji, M.; de Camargo, Z.P.; Gomes, G.M.; Franco, M.; Montenegro, M.R. Isolation of Paracoccidioides brasiliensis from armadillos (Dasypus noveminctus) captured in an endemic area of paracoccidioidomycosis. Am. J. Trop. Med. Hyg. 1998, 58, 505-512. [CrossRef] [PubMed]

17. Naiff, R.D.; Ferreira, L.C.L.; Barrett, T.V.; Naiff, M.F.; Arias, J.R. Paracoccidioidomicose enzoótica em tatus (Dasypus novemcinctus) no estado do Pará. Rev. Inst. Med. Trop. São Paulo 1986, 28, 19-27. [CrossRef]

18. Corredor, G.G.; Peralta, L.A.; Castano, J.H.; Zuluaga, J.S.; Henao, B.; Arango, M.; Tabares, A.M.; Matute, D.R.; McEwen, J.G.; Restrepo, A. The naked-tailed armadillo Cabassous centralis (Miller 1899): A new host to Paracoccidioides brasiliensis. Molecular identification of the isolate. Med. Mycol. 2005, 43, 275-280. [CrossRef]

19. Hrycyk, M.F.; Garcia Garces, H.; Bosco, S.M.G.; de Oliveira, S.L.; Marques, S.A.; Bagagli, E. Ecology of Paracoccidioides brasiliensis, P. lutzii and related species: Infection in armadillos, soil occurrence and mycological aspects. Med. Mycol. 2018. [CrossRef]

20. Eulalio, K.D.; de Macedo, R.L.; Cavalcanti, M.A.; Martins, L.M.; Lazera, M.S.; Wanke, B. Coccidioides immitis isolated from armadillos (Dasypus novemcinctus) in the state of Piaui, northeast Brazil. Mycopathologia 2001, 149, 57-61.

21. Arias, J.R.; Naiff, R.D.; Naiff, M.F.; Mok, W.Y.; Almeida, M.M. Isolation of Histoplasma capsulatum from an armadillo (Dasypus novemcinctus) in the eastern Amazon of Brazil. Trans. R. Soc. Trop. Med. Hyg. 1982, 76, 705-706. [CrossRef]

22. Vieira Gde, D.; Alves Tda, C.; Lima, S.M.; Camargo, L.M.; Sousa, C.M. Paracoccidioidomycosis in a western Brazilian Amazon State: Clinical-epidemiologic profile and spatial distribution of the disease. Rev. Soc. Bras. Med. Trop. 2014, 47, 63-68. [CrossRef] [PubMed]

23. Li, H.; Durbin, R. Fast and accurate short read alignment with Burrows-Wheeler transform. Bioinformatics 2009, 25, 1754-1760. [CrossRef]

24. Sahl, J.W.; Lemmer, D.; Travis, J.; Schupp, J.M.; Gillece, J.D.; Aziz, M.; Driebe, E.M.; Drees, K.P.; Hicks, N.D.; Williamson, C.H.D.; et al. NASP: An accurate, rapid method for the identification of SNPs in WGS datasets that supports flexible input and output formats. Microb. Genom. 2016, 2, e000074. [CrossRef] [PubMed]

25. DePristo, M.A.; Banks, E.; Poplin, R.; Garimella, K.V.; Maguire, J.R.; Hartl, C.; Philippakis, A.A.; del Angel, G.; Rivas, M.A.; Hanna, M.; et al. A framework for variation discovery and genotyping using next-generation DNA sequencing data. Nat. Genet. 2011, 43, 491-498. [CrossRef]

26. McKenna, A.; Hanna, M.; Banks, E.; Sivachenko, A.; Cibulskis, K.; Kernytsky, A.; Garimella, K.; Altshuler, D.; Gabriel, S.; Daly, M.; et al. The Genome Analysis Toolkit: A MapReduce framework for analyzing next-generation DNA sequencing data. Genome Res. 2010, 20, 1297-1303. [CrossRef]

27. Kurtz, S.; Phillippy, A.; Delcher, A.L.; Smoot, M.; Shumway, M.; Antonescu, C.; Salzberg, S.L. Versatile and open software for comparing large genomes. Genome Biol. 2004, 5, R12. [CrossRef]

28. Nguyen, L.T.; Schmidt, H.A.; von Haeseler, A.; Minh, B.Q. IQ-TREE: A fast and effective stochastic algorithm for estimating maximum-likelihood phylogenies. Mol. Biol. Evol. 2015, 32, 268-274. [CrossRef]

29. Kalyaanamoorthy, S.; Minh, B.Q.; Wong, T.K.F.; von Haeseler, A.; Jermiin, L.S. ModelFinder: Fast model selection for accurate phylogenetic estimates. Nat. Methods 2017, 14, 587-589. [CrossRef]

30. Minh, B.Q.; Nguyen, M.A.; von Haeseler, A. Ultrafast approximation for phylogenetic bootstrap. Mol. Biol. Evol. 2013, 30, 1188-1195. [CrossRef]

31. Anisimova, M.; Gascuel, O. Approximate likelihood-ratio test for branches: A fast, accurate, and powerful alternative. Syst. Biol. 2006, 55, 539-552. [CrossRef] [PubMed]

32. Jombart, T.; Ahmed, I. adegenet 1.3-1: New tools for the analysis of genome-wide SNP data. Bioinformatics 2011, $27,3070-3071$. [CrossRef] [PubMed]

33. Alexander, D.H.; Novembre, J.; Lange, K. Fast model-based estimation of ancestry in unrelated individuals. Genome Res. 2009, 19, 1655-1664. [CrossRef] [PubMed]

34. Sepulveda, V.E.; Marquez, R.; Turissini, D.A.; Goldman, W.E.; Matute, D.R. Genome Sequences Reveal Cryptic Speciation in the Human Pathogen Histoplasma capsulatum. MBio 2017, 8. [CrossRef] [PubMed] 
35. Ramasamy, R.K.; Ramasamy, S.; Bindroo, B.B.; Naik, V.G. STRUCTURE PLOT: A program for drawing elegant STRUCTURE bar plots in user friendly interface. Springerplus 2014, 3, 431. [CrossRef]

36. Borelli, D. Algunos aspectos ecologicos de la paracoccidioidosis. Derm. Venez. 1971, 10, 11.

37. Richini-Pereira, V.B.; Bosco Sde, M.; Griese, J.; Theodoro, R.C.; Macoris, S.A.; da Silva, R.J.; Barrozo, L.; Tavares, P.M.; Zancope-Oliveira, R.M.; Bagagli, E. Molecular detection of Paracoccidioides brasiliensis in road-killed wild animals. Med. Mycol. 2008, 46, 35-40. [CrossRef]

38. Corredor, G.G.; Castano, J.H.; Peralta, L.A.; Diez, S.; Arango, M.; McEwen, J.; Restrepo, A. Isolation of Paracoccidioides brasiliensis from the nine-banded armadillo Dasypus novemcinctus, in an endemic area for paracoccidioidomycosis in Colombia. Rev. Iberoam. Micol. 1999, 16, 216-220.

39. de Farias, M.R.; Condas, L.A.; Ribeiro, M.G.; Bosco Sde, M.; Muro, M.D.; Werner, J.; Theodoro, R.C.; Bagagli, E.; Marques, S.A.; Franco, M. Paracoccidioidomycosis in a dog: Case report of generalized lymphadenomegaly. Mycopathologia 2011, 172, 147-152. [CrossRef]

40. Ono, M.A.; Bracarense, A.P.; Morais, H.S.; Trapp, S.M.; Belitardo, D.R.; Camargo, Z.P. Canine paracoccidioidomycosis: A seroepidemiologic study. Med. Mycol. 2001, 39, 277-282. [CrossRef]

41. Trejo-Chavez, A.; Ramirez-Romero, R.; Ancer-Rodriguez, J.; Nevarez-Garza, A.M.; Rodriguez-Tovar, L.E. Disseminated paracoccidioidomycosis in a Southern two-toed sloth (Choloepus didactylus). J. Comp. Pathol. 2011, 144, 231-234. [CrossRef]

42. Mendes, J.F.; Klafke, G.B.; Albano, A.P.; Cabana, A.L.; Teles, A.J.; de Camargo, Z.P.; Xavier, M.O.; Meireles, M.C. Paracoccidioidomycosis infection in domestic and wild mammals by Paracoccidioides lutzii. Mycoses 2017. [CrossRef] [PubMed]

43. Hull, C.M.; Raisner, R.M.; Johnson, A.D. Evidence for mating of the "asexual" yeast Candida albicans in a mammalian host. Science 2000, 289, 307-310. [CrossRef] [PubMed]

44. Mavengere, H.; Mattox, K.; Teixeira, M.M.; Sepúlveda, V.E.; Gomez, O.M.; Hernandez, O.; McEwen, J.; Matute, D.R. Paracoccidioides genomes reflect high levels of species divergence and little interspecific gene flow. bioRxiv 2020. [CrossRef]

45. Maxwell, C.S.; Sepulveda, V.E.; Turissini, D.A.; Goldman, W.E.; Matute, D.R. Recent admixture between species of the fungal pathogen Histoplasma. Evol. Lett. 2018, 2, 210-220. [CrossRef] [PubMed]

46. Maxwell, C.S.; Mattox, K.; Turissini, D.A.; Teixeira, M.M.; Barker, B.M.; Matute, D.R. Gene exchange between two divergent species of the fungal human pathogen, Coccidioides. Evolution 2018. [CrossRef]

47. Matute, D.R.; Comeault, A.A.; Earley, E.; Serrato-Capuchina, A.; Peede, D.; Monroy-Eklund, A.; Huang, W.; Jones, C.D.; Mackay, T.F.C.; Coyne, J.A. Rapid and Predictable Evolution of Admixed Populations Between Two Drosophila Species Pairs. Genetics 2020, 214, 211-230. [CrossRef]

48. Martin, S.H.; Davey, J.W.; Salazar, C.; Jiggins, C.D. Recombination rate variation shapes barriers to introgression across butterfly genomes. PLoS Biol. 2019, 17, e2006288. [CrossRef]

49. Schumer, M.; Xu, C.; Powell, D.L.; Durvasula, A.; Skov, L.; Holland, C.; Blazier, J.C.; Sankararaman, S.; Andolfatto, P.; Rosenthal, G.G.; et al. Natural selection interacts with recombination to shape the evolution of hybrid genomes. Science 2018, 360, 656-660. [CrossRef]

50. Moyle, L.C.; Nakazato, T. Hybrid incompatibility “snowballs" between Solanum species. Science 2010, 329, 1521-1523. [CrossRef]

51. Matute, D.R.; Butler, I.A.; Turissini, D.A.; Coyne, J.A. A test of the snowball theory for the rate of evolution of hybrid incompatibilities. Science 2010, 329, 1518-1521. [CrossRef] [PubMed]

52. Wang, R.J.; White, M.A.; Payseur, B.A. The Pace of Hybrid Incompatibility Evolution in House Mice. Genetics 2015, 201, 229-242. [CrossRef] [PubMed]

53. Chhina, A.K.; Thompson, K.A.; Schluter, D. Adaptive divergence and the evolution of hybrid phenotypes in threespine stickleback. bioRxiv 2020. [CrossRef]

54. Macedo, R.L.; Lazera Mdos, S.; Trilles, L.; Reisr, R.S.; Bulcão, A.S.; Silva, N.J.; Oliveira, N.A.; Wanke, B. Infecção natural de tatus por Paracoccidioides brasiliensis em serra da mesa, Minaçu, Goiás: Estudo preliminar. In Proceedings of the II Congresso Brasileiro de Micologia, Rio de Janeiro, Brazil, 17-21 April 1998.

55. Vergara, M.L.; Martinez, R. Role of the armadillo Dasypus novemcinctus in the epidemiology of paracoccidioidomycosis. Mycopathologia 1998, 144, 131-133. [CrossRef] [PubMed]

56. Naiff, R.D.; Barret, T.V. Novos registros de Paracoccidioides brasiliensis em tatus (Dasypus novemcinctus). In Proceedings of the Congresso Brasileiro Parasitologia, Rio de Janeiro, Brazil, 30 July-3 August 1989. 